For personal use only. Not to be reproduced without permission of the publisher (editorial@gabi-journal.net).

\title{
Biosimilarity in Latin America
}

\author{
Chang Chiann', PhD; Leonardo de Souza Teixeira², PhD; Fabiana \\ Fernandes de Santana e Silva Cardoso ${ }^{2}$, MSc; Isabela da Costa César ${ }^{2,3}$, \\ PhD; Gerson Antônio Pianetti ${ }^{3}$, PhD
}

\section{The introduction of new legislation in Latin America for the approval of biosimilar products follows implementation of EU legislation in 2005 for biosimilars approval. The estab- lishment of regulatory processes for these complex drugs will ensure that evidence of safety and efficacy is obtained before approval. Biosimilars are high on the health-policy agenda because they are less costly and potentially more accessible, and also because of the imminent expiration of a number of patents on biological products. Within indi- vidual Latin American countries, the regulatory processes and stages of implementation vary.}

Keywords: Biosimilarity, complex drugs, Latin America

\begin{abstract}
Introduction
Many people in Latin American countries still have difficulty accessing medicines to improve their health and quality of life, despite an increasing number of pharmaceutical products on the market. The World Health Organization (WHO) has recommended the use of the essential drug lists to guide the selection, registration and procurement of drugs by governments, to ensure access to medicines at an affordable price. For small-molecule drug products, generic formulations are considered an important health-policy issue in most Latin American countries, mainly because of reduced costs and social benefits provided by the government. The demonstration of interchangeability of generic formulations with the reference formulation has been a requirement in some Latin American countries since $1970[1,2]$.
\end{abstract}

Biotherapeutic products account for a large percentage of the government health budget, because of the number of expiring patents on biological products due in the next few years. An important issue for discussion is the use of biosimilar products because of their accessibility and economic rele- vance. Most governments in Latin America are interested in improving access to more affordable biotherapeutic products; however, quality, safety and efficacy of these products are always a concern. Unlike small molecule generics, copies of biological products can be similar, but not identical, to innovator biologicals. Thus, the generic versions of biological products are referred to as 'similar biological drug products'. These products are usually referred to as biosimilar products by the European Medicines Agency (EMA), follow-on biologics by the US Food and Drug Administration (FDA), or subsequently entered biologics by the Public Health Agency of Canada [3]. In Brazil, the new biotherapeutic products are called new biological products, and the copies are called biological products that can be licensed by the comparative pathway or the individual development pathway [4].

The biosimilar concept can often be misinterpreted and used inconsistently, and the potential implication of this is a concern. These include negative perception and impaired acceptance of biosimilars among prescribing physicians and patients $[5,6]$. Biosimilar products may be defined as

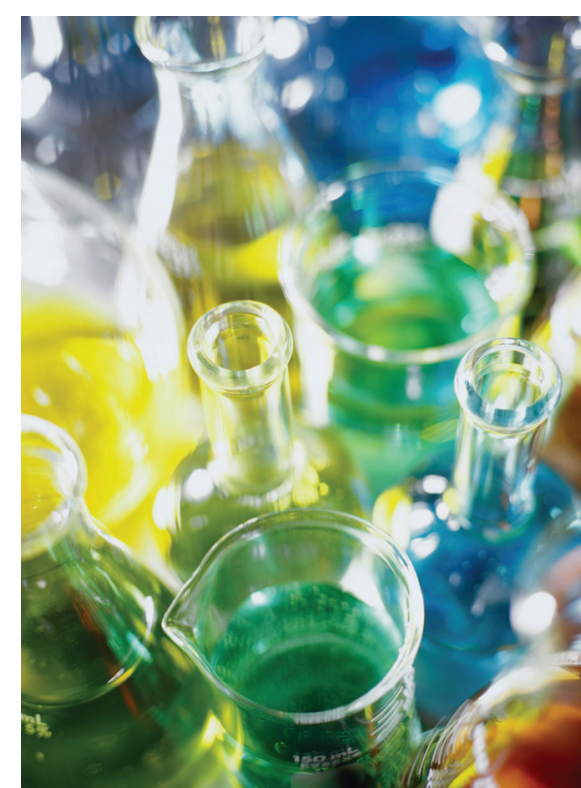

a copy version of previously authorized biological medicinal products that demonstrate similarity in physicochemical characteristics, efficacy and safety, based on a comprehensive comparability exercise. On the other hand, biologicals or biocopies are biological medicinal products that are developed on their own and not directly compared and analyzed against a licensed new biological. It is unknown whether, and which, physicochemical differences exist compared with other biological of the same class [5].

The development of biologicals is complex and has high associated costs. Only a few pharmaceutical companies in Latin American countries are able to provide biosimilar products [7]. A regulatory policy for biosimilars is being developed in several Latin American countries and, in general, follows guidelines that were established either by WHO or EMA [8]. In addition, the appropriate use of generic and biosimilar medications is important for maintaining financial equilibrium within the health system [9].

In this paper, we aim to review the current issues on biosimilarity of pharmaceutical formulations in Latin American countries. In addition, we refer to legislation in different countries and present future perspectives.

Author for correspondence: Chang Chiann, PhD, Department of Statistics, Institute of Mathematics and Statistics, University of São Paulo, Rua do Matão, 05315-970, São Paulo, SP, Brazil

Submitted: 18 December 2012; Revised: 18 March 2013; Accepted: 11 April 2013; Published online first: 17 April 2013 


\section{Biosimilars development in Latin American countries}

Biosimilar products aim to mimic the innovator product in molecular size and complexity during the manufacturing process; however, minor changes in production can have serious implications on safety and efficacy. Like all biologicals, the main problem related to the safety of a biosimilar is its immunogenicity [8, 10]. Therefore, the approval of biosimilar products requires the performance of pharmacokinetic, preclinical and clinical analytical studies, such as physicochemical assays, biological and immunological tests. These issues have been established by WHO, and have been incorporated into the main drug registry entities worldwide [11]. In addition, it is essential to implement a pharmacovigilance system after product commercialization, so that safety and efficacy of biosimilar products can be evaluated [10].

The establishment of regulatory processes for structurally complex drugs such as biosimilars is a long-standing challenge, and has become increasingly urgent owing to rapid technological advances and the expiration of innovator patents in this class [12]. Legislation for biosimilars approval in the EU was implemented by the Committee for Medicinal Products for Human Use of EMA in 2005. Both preclinical in vitro assays and in vivo animal and clinical studies in patients are required to compare the biosimilar product with the reference product. In the US, several natural source products and recombinant proteins have already been approved as similar drugs under Section 505(b)(2) of the Food, Drug, and Cosmetic Act [13].

In Latin America, the regulation of biosimilars varies considerably between different countries, and some of the so-called biosimilars were approved before an adequate clinical test was carried out [8]. In some countries, the lack of interchangeability for some biosimilar products becomes a serious concern in the health system, when a reference medicine is substituted by a multisource product. Hence, some guidelines and legislative purposes on biosimilar medicines began to be introduced in Latin America [7]. Currently, clinical issues have been defined and have continually been revised. These issues include indications of differences in the amino acid chain and in the glycosylation patterns on biochemical quality side and the kind of clinical trial to be carried out [8].

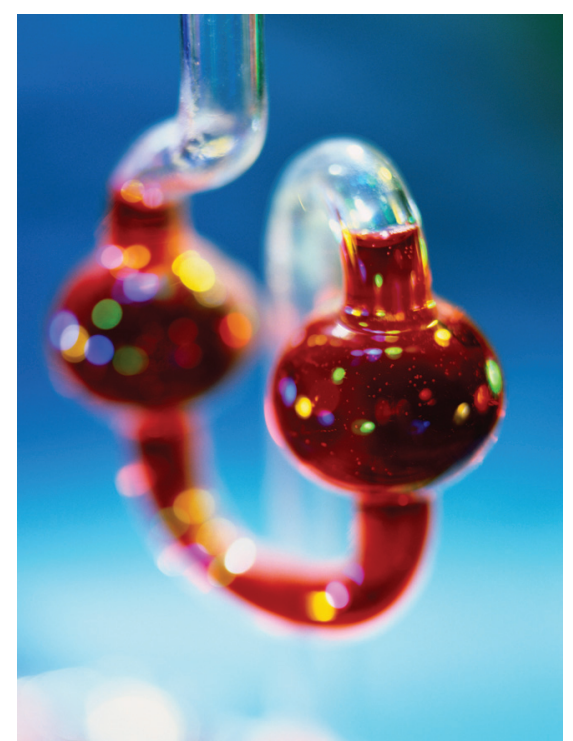

\section{Brazil}

In Brazil, the Agência Nacional de Vigilancia Sanitária is in charge of regulating biologicals and biosimilars. The resolution RDC $55 / 2010$ was published in 2010. This regulation has different and specific regulatory pathways for new biological products and for copies. This resolution establishes the minimum requirements for the approval of biological products in Brazil, aiming to assure the quality, safety and efficacy of these medicines [14]. For the similar biotherapeutic products, two regulatory pathways, a comparative pathway and an individual development pathway, are in place. The comparability pathway is more rigorous and requires comparative phase I, II, and III trials to the originator biological product, and will allow extrapolation into other indications. At least one comparative phase III study (equivalence or non-inferiority) with the originator (new) biological product is mandatory. In the individual development pathway, a reduced dossier can be presented. The applicant needs to present complete data on quality issues, but it does not have to be comparative. Nonclinical and clinical studies can be reduced, depending on the amount of knowledge of pharmacological properties, safety and efficacy of the originator product. Extrapolation of indications will not be accepted in the individual development pathway [4].

In 2011, a recent guideline was published to elucidate the regulatory requirements for the comparability exercise regarding the quality criteria of the biological products. The evaluation criteria for the quality of biological products involve available analytical techniques, biochemical characterization, physicochemical and immunochemical properties, biological activity, and impurities. Besides the use of quality data, the registration of a biological product requires non-clinical and clinical studies. The extent of these non-clinical and clinical data depends directly on the product class, level of characterization for modern analytical methods, differences observed on the reference product, and clinical experience with the product class [15].

\section{Chile}

Until 2011, no specific regulatory pathway was in place for biosimilars in Chile.

All products were required to provide the full complement of clinical studies to gain registration, as they considered that the similar drugs available had a different chemical composition because they were manufactured through different processes [11]. In 2011, Chile's Agencia Nacional de Medicamentos (ANAMED) released $\mathrm{draft}$ guidance for the evaluation of biosimilars. Chile has referenced the EMA and WHO guidelines in developing a regulatory pathway for biosimilars. This future regulatory law will ask manufacturers to provide comparative studies with the reference drug to characterize the product adequately and to demonstrate biosimilarity. This will most likely include phase I, II, and III comparative studies, and may allow for extrapolation of indications [16].

\section{Other Latin American countries}

In Argentina, legislation numbers 7075 and 7729 were published in 2011. These legislations stated the requirements for biosimilar products, as well as non-clinical and clinical studies, to have these products approved. In Mexico, the Ley Orgánica de la Administracion Pública Federal is the legislation on biosimilars registration; however, the requirements are vague, and regulatory authorities need to conduct the kind of clinical studies that will be required for approving individual drugs. The Decree No. 37006 was published in 2012 in Costa Rica. It states the biosimilar regulations on the basis of international guidelines. Currently, no other countries are in the process of creating their regulations. Some of these countries have decided to open discussions with the academic community, such as Colombia [8].

\section{Conclusion}

Although the introduction of biosimilars 
to the market has its advantages, some medical professionals are still not familiar with the definition of biosimilars. In addition, it is important to assure total transparency from all the parties involved with the regulation and approval processes of those treatments [10, 13].

Biosimilar products are gradually being introduced into clinical practice. In the near future, the agents with increased complexity will be introduced into the global markets. These products may potentially reduce healthcare costs. Some uncertainties are related to its safety and efficacy, particularly when reference biological drugs have multiple indications. Therefore, assuring the safety and efficacy of biosimilars by means of non-clinical and clinical studies is crucially required, as patients' welfare is much more relevant than any economic interest involved $[17,18]$.

\section{Competing interests: None.}

Provenance and peer review: Commissioned; externally peer reviewed.

\author{
Authors \\ Chang Chiann ${ }^{1}, \mathrm{PhD}$ \\ Leonardo de Souza Teixeira ${ }^{2}$, PhD \\ Fabiana Fernandes de Santana e Silva \\ Cardoso $^{2}, \mathrm{MSc}^{2}$ \\ Isabela da Costa César ${ }^{2,3}, \mathrm{PhD}$ \\ Gerson Antônio Pianetti ${ }^{3}$, PhD \\ ${ }^{1}$ Department of Statistics, Institute of \\ Mathematics and Statistics, University of \\ São Paulo, SP, Brazil \\ ${ }^{2}$ Institute of Pharmaceutical Sciences, Goiania, \\ GO, Brazil \\ ${ }^{3}$ Department of Pharmaceuticals, Faculty
}

of Pharmacy, Federal University of Minas Gerais, Belo Horizonte, MG, Brazil

\section{References}

1. Homedes N, Ugalde A. Multisource drug policies in Latin America: survey of 10 countries. Bull World Health Organ. 2005 Jan;83(1):64-70.

2. Estévez F, Parrillo S, Cedrés M. Estúdios de bioequivalencia in vivo para demostrar la intercambiabilidad de medicamentos. [In vivo bioequivalence studies to demonstrate the interchangeability of medicines]. Rev Med Urug. 2012;28(3):165-73. Spanish.

3. Chow S, Ju C. Assessing biosimilarity and interchangeability of biosimilar products under the Biologics Price Competition and Innovation Act. Generics and Biosimilars Initiative Journal (GaBI Journal), 2013;2(1):20-5. doi:10.5639/gabij.2013.0201.004

4. Castanheira LG, Barbano DBA, Rech N. Current development in regulation of similar biotherapeutic products in Brazil. Biologicals. 2011;39(5):308-11.

5. Weise M, Bielsky MC, De Smet K, Ehmann F, et al. Biosimilars-why terminology matters. Nat Biotechnol. 2011;29(8):690-3.

6. Thorpe R, Wadhwa M. Terminology for biosimilarsa confusing minefield. Generics and Biosimilars Initiative Journal (GaBI Journal). 2012;1(3-4):132-4. doi:10.5639/gabij.2012.0103-4.023

7. Inesta A, Oteo LA. La industria farmacéutica y la sostenibilidad de los sistemas de salud en países desarrollados y América Latina [The pharmaceutical industry and the sustainability of the health systems in developed countries and Latin America]. Ciênc. Saude Coletiva. 2011;16(6):2713-24. Spanish.

8. Mysler E, Scheinberg M. Biosimilars in rheumatology: a view from Latin America. Clin Rheumatol. 2012;31(9):1279-80

9. Chen ML, Shah VP, Crommelin DJ, Shargel L, et al. Harmonization of regulatory approaches for evaluating therapeutic equivalence and interchangeability of multisource drug products: workshop Summary Report. AAPS J. 2011;13(4):556-64.

10. Azevedo VF, Felippe LR, Machado DM. Opinion of some Brazilian rheumatologists about biosimilars. Rev Bras Reumatol. 2011;51(6):667-71.

11. Saavedra I, Quinones L. Intercambiabilidad de medicamentos de origen biológico (biofármacos): Consideraciones acerca de la aprobación de formulaciones biosimilares (biogenéricos) en Chile. Considerations about the approval of biosimilar formulations (biogenerics) in Chile. [Interchangeability of biological drugs: considerations about the approval of biogeneric formulations in Chile] Rev Méd Chile. 2006;134:1583-8. Spanish.

12. Ahmed I, Kaspar B, Sharma U. Biosimilars: impact of biologic product life cycle and European experience on the regulatory trajectory in the United States. Clin Ther. 2012;34(2):400-19.

13. Kay J. Biosimilars: a regulatory perspective from America. Arthritis Res Ther. 2011;13(3):112-6.

14. Ministério da Saúde, Brasil. Agência Nacional de Vigilância Sanitária. Resolução RDC n55, de 16 de dezembro de 2010 [homepage on the Internet] [cited 2013 Mar 18]. Spanish. Available from: http://bvsms.saude.gov.br/bvs/saudelegis/ anvisa/2010/res0055_16_12_2010.html

15. Ministério da Saúde. Brasil. Agência Nacional de Vigilância Sanitária. Guia para Realização do Exercício de Comparabilidade para Registro de Produtos Biológicos. Brasília, 2011 [homepage on the Internet]. [cited 2013 Mar 18]. Spanish. Available from: www.portal.anvisa.gov.br/wps/wcm/ connect/321df880 48bd2560a 7c3af9a6e94f0d0/ produtos_biologicos_exercicio.pdf

16. Azevedo VF, Sandorff E, Siermak B, Halbert RJ. Potential regulatory and commercial environment for biosimilars in Latin America. Value in health regional issues. 2012;1(2):228-34.

17. Dranitsaris G, Dorward K, Hatzimichael E, Amir E. Clinical trial design in biosimilar drug development. Invest New Drugs. 2013 Apr;31(2)479-87.

18. Cardoso FFSS. Medicamentos biológicos e biossimilares. [Biological and biosimilar medicines] Edição Brasileira. 2012;16(1):38-40. Spanish.

DOI: 10.5639/gabij.2013.0202.021

Copyright (c) 2013 Pro Pharma Communications International 